\title{
DEVELOPING GUIDED DISCOVERY LEARNING MATERIALS USING MATHEMATICS MOBILE LEARNING APPLICATION AS AN ALTERNATIVE MEDIA FOR THE STUDENTS CALCULUS II
}

\author{
Sunismi \\ Teaching and Educational Science Faculty of Malang Islamic University \\ email: sunismiunisma@yahoo.com
}

\begin{abstract}
The development research aims to develop guided-discovery learning materials of Calculus II by implementing Mathematics Mobile Learning (MML). The products to develop are MML media of Calculus II using guided discovery model for students and a guide book for lecturers. The study employed used 4-D development model consisting of define, design, develop, and disseminate. The draft of the learning materials was validated by experts and tried-out to a group of students. The data were analyzed qualitatively and quantitatively by using a descriptive technique and t-test. The findings of the research were appropriate to be used ad teaching media for the students. The students responded positively that the MML media of Calculus II using the guided-discovery model was interestingly structured, easily operated through handphones (all JAVA, android, and blackberry-based handphones) to be used as their learning guide anytime. The result of the field testing showed that the guided-discovery learning materials of Calculus II using the Mathematics Mobile Learning (MML) application was effective to adopt in learning Calculus II.
\end{abstract}

Keywords: learning materials, guided-discovery, mathematics mobile learning (MML), calculus II

\section{PENGEMBANGAN BAHAN AJAR MODEL GUIDED DISCOVERY DENGAN APLIKASI MATHEMATICS MOBILE LEARNING SEBAGAI ALTERNATIF MEDIA PEMBELAJARAN MAHASISWA MATAKULIAH KALKULUS II}

\begin{abstract}
Abstrak: Penelitian pengembangan ini bertujuan untuk mengembangkan bahan ajar matakuliah Kalkulus II model guided discovery dengan aplikasi Mathematics Mobile Learning (MML). Produk yang dikembangkan berupa media MML Kalkulus II dengan model guided discovery untuk mahasiswa dan buku panduan dosen. Model pengembangan menggunakan 4-D yang meliputi tahap define, design, develop, dan dissemination. Draf bahan ajar divalidasi oleh pakar dan diujicobakan kepada sejumlah mahasiswa. Data dianalisis secara kualitatif dan kuantitatif dengan teknik deskriptif dan uji t. Temuan penelitian bahan ajar ini sangat tepat digunakan sebagai media pembelajaran bagi mahasiswa. Mahasiswa memberikan tanggapan positif bahwa media MML Kalkulus II dengan model guided discovery disusun menarik, dapat dioperasikan dengan mudah melalui HP (semua HP berbasis JAVA, android, dan blackberry) sehingga dapat digunakan panduan belajar mahasiswa kapan saja. Hasil uji lapangan diperoleh bahwa bahan ajar matakuliah Kalkulus II model guided discovery dengan aplikasi Mathematics Mobile Learning (MML) efektif digunakan dalam pembelajaran matakuliah Kalkulus II.
\end{abstract}

Kata Kunci: bahan ajar, guided discovery, Mathematics Mobile Learning (MML), Kalkulus II

\section{INTRODUCTION}

Mathematics is one of the disciplines that supports others, such as natural and social sciences. Due to its important role, mathematics is taught in every educational unit and every grade with more teaching hours when compared to other subjects.

Unfortunately however, there are still many students considering that mathematics is no more than merely calculating and playing 
with formulas and numbers. Actually mathematics is taught because it trains the students to think and argue, not only training the left brain - thinking logically, analytically, critically, in detail, and sequentially, but also the right brain - thinking alternatively, exploratively and creatively, and developing the ability of designing and optimizing. Through mathematics, the students can also be accustomed to work efficiently, always try to find simpler and shorter ways (without reducing the effectiveness), be careful and not careless, be strict in arguing, and be cooperative, so they can to respond to the globalization era as well as the rapid development of science and technology today and in the future.

Calculus II is a subject of knowledge and skill with a total credit of three. This course is important to master as it serves as the basis for other courses. It is a prerequisite for taking the next courses, such as advanced calculus, differential equation, real analysis, numeric method, and mathematics statistics.

So far the learning process in Calculus II has always been taken from concepts, theorems, and algorithms and has not ended in solving daily problems. To overcome the constraints, learning resources in the form of learning materials that can provide the students with the opportunity to develop themselves and to facilitate their learning need to be developed.

The learning materials developed in this study are designed to be challenging, inductive, instead of deductive, in discovering fomulas. The teaching metarials are based on the guided discovery method as through this model the students can learn to discover concepts or principles (theorems, formulas, characteristics) themselves in the materials they learn. The materials will be able to arouse enthusiasm, alternative thinking ability, ability to explore and express ideas and feelings, skills of exploring thoughts, autonomy of solving problems, etc. In this case, the students are demanded to think exploratively more than merely to think mechanically and procedurally.

The learning materials developed by using guided-discovery need to be varied by using other media to eliminate the negative effects and to make the teaching of Calculus II more interesting as well as to strengthen the students' conceptions. One variation is the use of the information and communication technology developments, one of which is the application of mobile learning. It enables the developer to carry out many things, including the contextual, actual, factual, innovative, and interesting learning materials using multimedia.

Along with the increasing development of information and communication technology, a lot of mobile applications have been developed. The development of technology has also given rise to a new learning concept, namely elearning. The computer-based internet learning materials are commonly called e-learning. Wahono (2005:2) states that e-learning is an educational system or concept utilizing the information technology in the teaching and learning process. The development of e-learning and mobile applications have created a new type of learning, namely mobile learning. If e-learning is a learning concept in which the learning process can take place anywhere and anytime by using computers and internet, mobile learning is the development of e-learning by using handphones as a means of conducting learning.

Ally, et al (2005:1) define m-learning as the delivery of electronic learning materials on mobile computing devices to allow access from anywhere and at anytime. In line with them, Andy (2007:6) states that mobile learning or mlearning is often defined as e-learning through mobile computation. According Yuniati (2011: 91) mobile learning modifies handphones used to function only as a means of sending messages, telephoning, accessing the internet into complete learning tools containing learning materials, test questions, try outs equipped with the features of search, jump to and back.

With mobile learning, someone can learn at a more flexible time and place than that carried out with the concept of e-learning (Tamimuddin, 2008:2). The learning by using $\mathrm{m}$ learning can be easily carried and used anywhere. As a result, m-learning enables the learners to learn at a more flexible time and 
place (Wijaya, 2006:89). Based on the research conducted by a project of m-learning in England, Italy, and Sweden (Attewell, 2005:2), mlearning has the following benefits: (1) it provides real learning wherever and whenever; (2) it can be used to enliven or add more variations to the conventional learning; (3) it can be used to eliminate some formality that non-traditional learners consider uninteresting or terrifying and that can make lessons more interesting; and (4) it facilitates the learning experience both individually and collaboratively.

One of the applications of mobile learning developed by P4TK (Centre for Research and Empowerment of Teachers and Teaching Staff) of Mathematics of National Education Ministry of the Republic of Indonesia in 2008 was Mathematics Mobile Learning (MML) (Tamimuddin, 2008:2). It is a model of learning mathematics employing mobile devices, especially handphones so that they can be used for learning wherever and whenever. The Mathematics Mobile Learning (MML) contains mathematics learning materials for junior and senior high school students expected to enrich the altenative ways of learning mathematics. This development of MML for the junior and senior high schools students inspires the development of the application of Mathematics Mobile Learning for university students.

Based on the discussion above, the objectives to achieve in this research and development is developing the learning materials of Calculus II by using the application of Mathematics Mobile Learning (MML), that can be easily accessed through handphones by the students wherever and whenever, and meets the qualification of high quality learning media. More specifically the products are firstly, the media of Mathematics Mobile Learning (MML) of Calculus II by using the guided discovery model for their mobile access and learning through handphones and secondly, a guide book for lecturers to implement the course book in conducting the teaching process.

\section{METHOD}

This study adopts development research method. Waldopo (2002:89) defines research and development as an approach in developing products in the field of education. In this study guide discovery-based learning materials of Calculus II by using the application of Mathematics Mobile Learning (MML) is developed as an alternative learning media for students so that it can be accessed and operated through handphones.

The development model refers to Thiagaradjan, Semmel and Semmel's (1974) known as 4-D model. This model consists of four main phases, namely (1) define (pre and post analysis (students and lecturers' needs), analysis of students (students' characteristics), task analysis, concept analysis, and formulation of indicators (learning objectives); (2) design (media selection, format selection, and development of the first design); (3) develop (development of learning materials of Calculus II, evaluation by experts, expert validation and small scale try out ); and (4) disseminate (field try-out/ validity test of learning materials of Calculus II and packaging the ready made learning materials).

There are two types of data in this study firstly, qualitative data namely, the information obtained from the results of documentation, questionnaires on the students and lecturers' needs, questionnaires on the experts and practitioners' judgment, and observations and secondly, quantitative data namely, information collected from the results of the pre-test and post-test on the test of the product effectivity. In this study the data collection techniques are (1) documentation; (2) questionnaires; and (3) tests.

The try-out subjects in this study are three experts, two practitioners, and a group of students. The three experts are an instructional media and design expert, a mathematics instruction expert, and a mathematics expert. The two practitioners are two lecturers of Calculus II. The try-out subjects are a group of students and the subjects of the product effectivity test are the semester two students of Mathematics Education Study Program of Teaching and 
Educational Science Faculty of Malang Islamic University taking Calculus II.

Two data analysis techniques were employed in this study. Firstly, the data were descriptively qualitatively analysed, meaning that the data in the form of information were collected through the questionnaires from the experts, practitioners/lecturers, and students' responses. Secondly, the data were quantitively analysed by employing descriptive statistics, especially the numerical ones, namely those obtained from the field test or effectiveness test of the product.

The research design for the effectiveness test of the product was quasi experimental design as it was impossible to assign the subjects into the experimental and control groups randomly. This study was conducted among the students assigned in a certain class that could not be separated. The type of the research design was a pre-test -post-test control group design (Tuckman, 1999:167). The data analysis technique used was $t$ test (test for equal means) by first conducting a parametric prerequisite, namely the normality test by using Lilliefors (Kolmogorov-Smirnov) Normality Test and Levene's Test of Equality of Error Variances was used to test the homogeneity of variance across groups. The Statistical Package for Social Sciences (SPSS) version 17.00 (Ghozali, 2006) was used for all tests and data analyses in this study. The sampling technique used was purposive sampling, in which according to Sugiyono (2006:61) the selection of a group of subjects was based on certain characteristics, namely the students who had handphones which could access the MML materials of Calculus II both online and offline.

\section{FINDINGS AND DISCUSSION}

\section{The Results of Analysing the Students and Lecturers' Needs}

In this study the data of need analysis of the students and lecturers on the learning of Calculus II were obtained from the students and lecturers of four universities, namely UMM Malang, UNIDA Malang, UNIM Mojokerto, and UNISMA Malang, with 166 students who have taken Calculus II and four lecturers of Calculus II as the research subjects.

The needs analysis was carried out to find out the needs of the students and lecturers in supporting the learning process of Calculus II. The results of the needs analysis showed that $75.3 \%$ of the students found it difficult to learn Calculus II because the learning materials were the textbooks sold on the market. The textbooks were abstractly written. Therefore, $68.04 \%$ of the students were pleased when in the learning of Calculus II, the lecturers always gave them the opportunity to find formulas/concepts/principles themselves. Also, 59.7\% of the students were happy when the learning materials of Calculus II were written based on the guided discovery model with the application of Mathematics Mobile Learning, where they found the formulas/concepts/principles themselves and could access the learning materials through handphones so that they could learn whenever and wherever.

The results of the needs analysis of the lecturers' showed that $75 \%$ of them still taught Calculus II by lecturing and only 50\% used media like power point, blog, internet, etc. All lecturers who became the respondents in this study agreed that if the learning materials of Calculus II were developed based on the guided discovery model with the application of Mathematics Mobile Learning, the students could learn through handphones to enable them to learn the materials whenever and wherever.

Based on the analysis of the students' characteristics in relation to their competence in Calculus II, it was shown that $67.26 \%$ of the students did not have adequate understanding and even had no understanding of Calculus II learning materials. Therefore, the development of such learning materials was badly needed to help them learn easily.

\section{The Results of the Product Development}

The products developed in this study were guided discovery model-based MML media of Calculus II for the students and a guide book for the lecturers. The media used the application of Mathematics Mobile Learning 
(MML) so that it could be operated through handphones. To develop the application of Mathematics Mobile Learning (MML) some softwares such as Microsoft word, Snagit, Corel Draw X3, Adobe Photoshop X3, and Netbeans IDE were utilized. To run the MML application, the handphones with JAVA program (Java 2 Mobile Edition (J2ME)) were used. Besides, android handphones or blackberry could also be used.

The guided discovery model-based MML media of Calculus II cover the materials of: (1) indeterminate integrals; (2) integration techniques (consisting of: 2.1 Substitution techniques and partial integrals; 2.2 Integral of trigonometric functions and integral of trigonometric substitution; 2.3 Integral of rational functions and rational trigonometry); (3) definite integrals; and (4) applications of definite integrals (consisting of: 4.1 Area of flat surface. 4.2 Volume of solids of revolution. 4.3 Volume of solids, length of curve, surface area of solids of revolution; 4.4 Moment, mass centres, and force). All materials were developed interestingly by using simple language to be easily understood.

Each material has the following framework: (1) Main Menu, (Figure 1); (2) Content Menu of Calculus II, consisting of introduction menu, menu of discovery discussion, menu of checking understanding, and worksheet menu (Figure 2); (3) Menu of Competence Test (Figure 3).
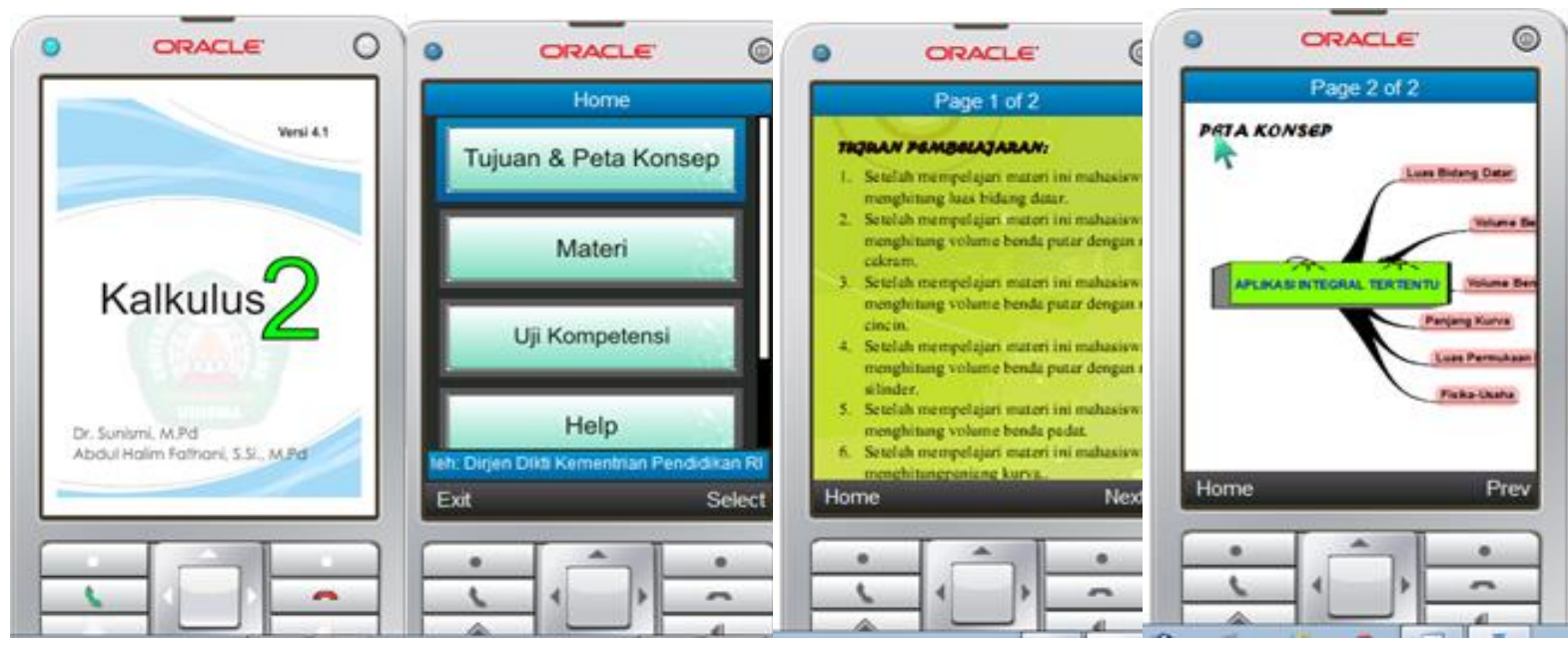

Figure 1. Main Menu
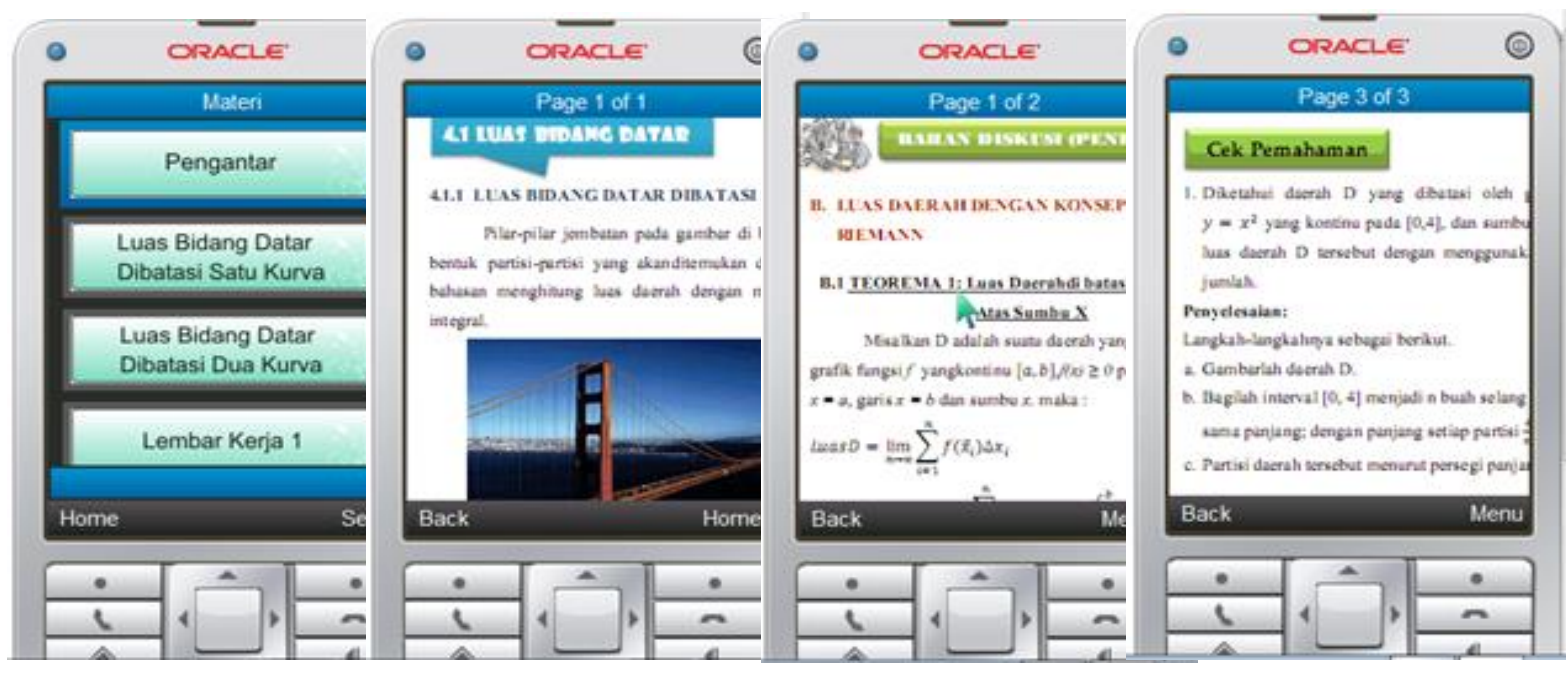

Figure 2: Content Menu of Calculus 

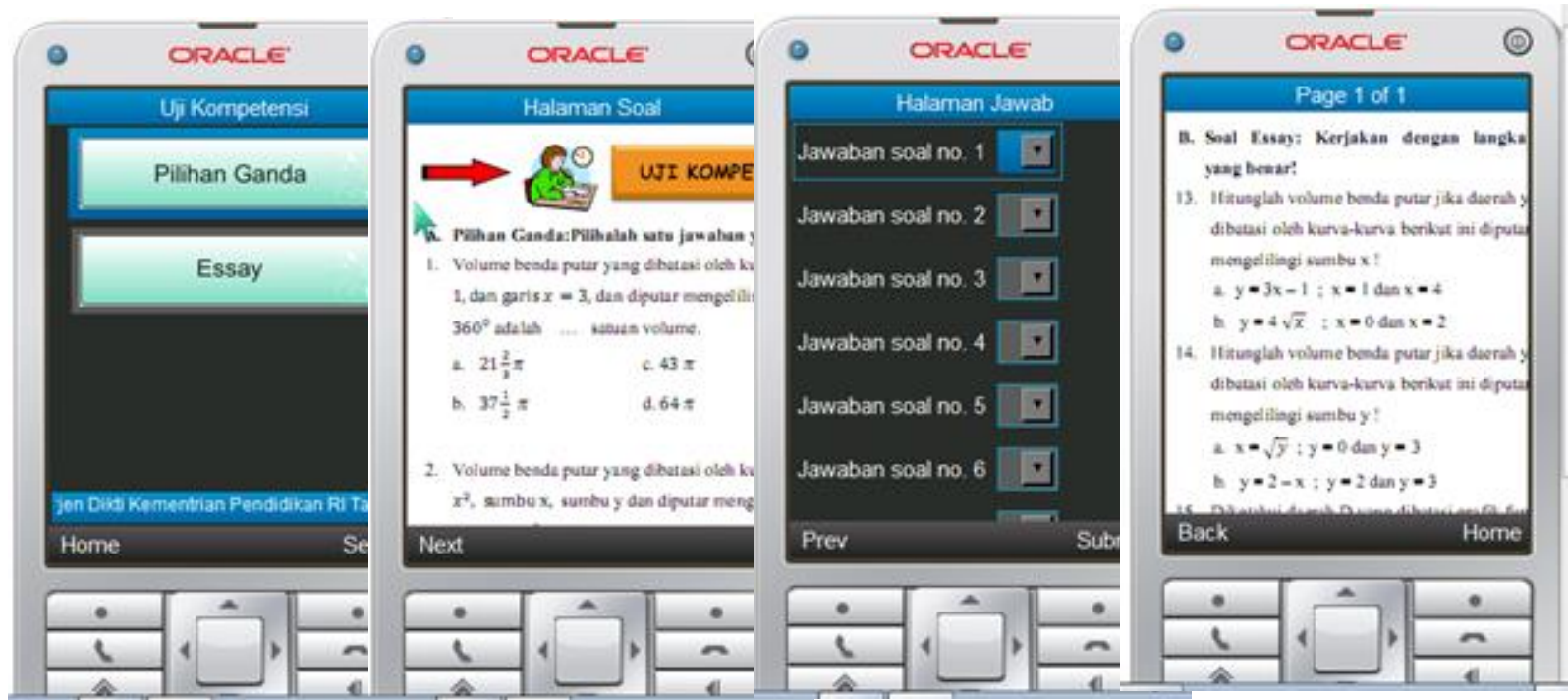

Figure 3. Competence Test Menu

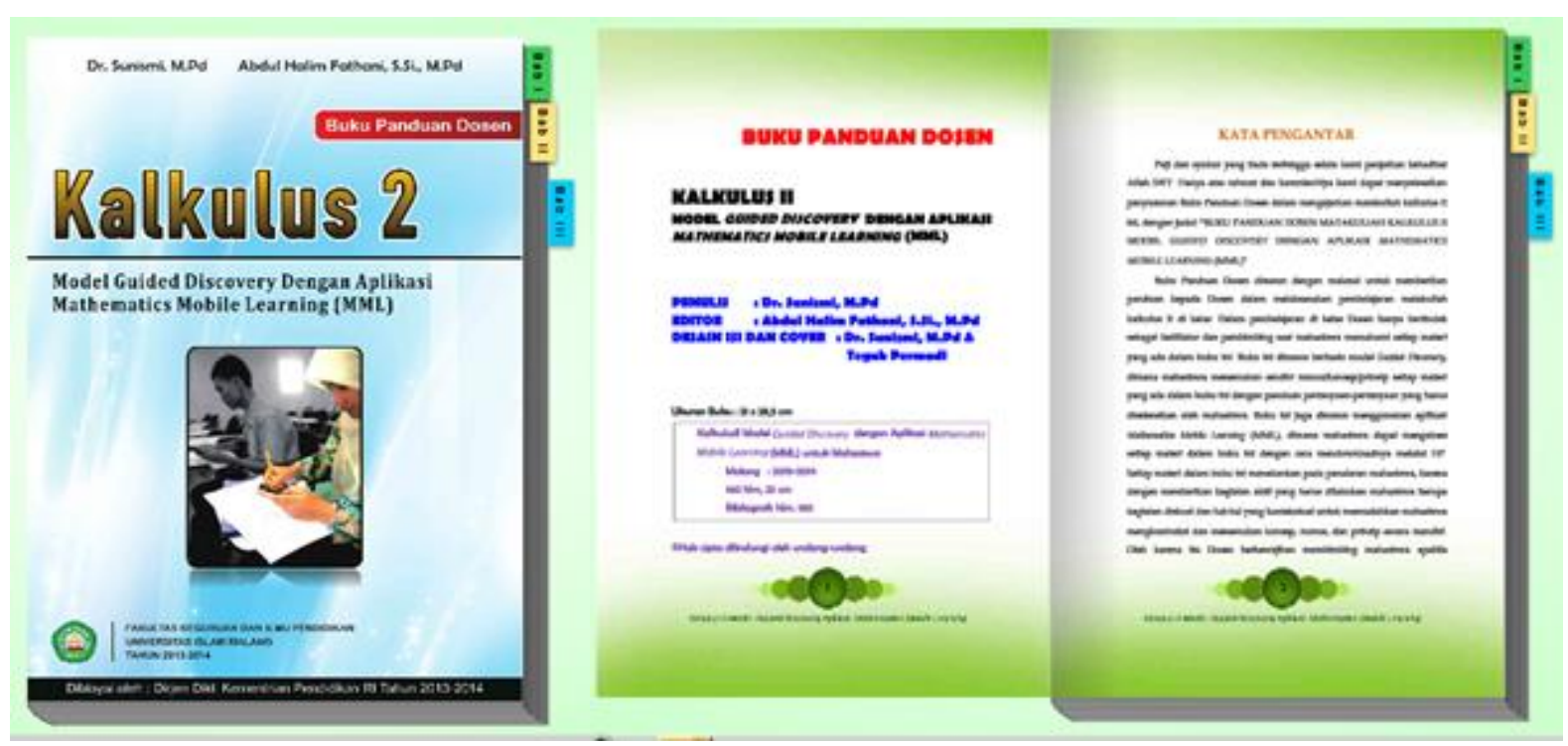

Figure 4: Front Pages of the Guide Book for Lecturers

The development of a guide bok for the lecturers is aimed at providing the lecturers guidance in implementing the MML media of Calculus II in the teaching process. The guide book is put into e-book in the form of Flip Book Maker, so that it can be opened and read like a book through laptops/computers with an interesting display. The front pages of the book consist of: e-book cover, identity of the book, preface, directions of how to use the book, and table of content (Figure 4).

The guide book includes the following parts: (1) The General Guidelines for the Teaching of MML of Calculus II, containing the directions of implementing, accessing, and operating MML of Calculus II in the teaching process, which consist of the course description, description of MML (how to access and operate MML through handphones), evaluation, formulation of indicators and learning objectives, and time allocation (Figure 5); (2) The Teaching of Mathematics Mobile Learning (MML) of Calculus II, containing the lesson plans of MML of each material in Calculus II (Figure 6); (3) The Answer Key of the Competence Test, containing the answer key of the multiple choice questions in the competence test (Figure 7). 


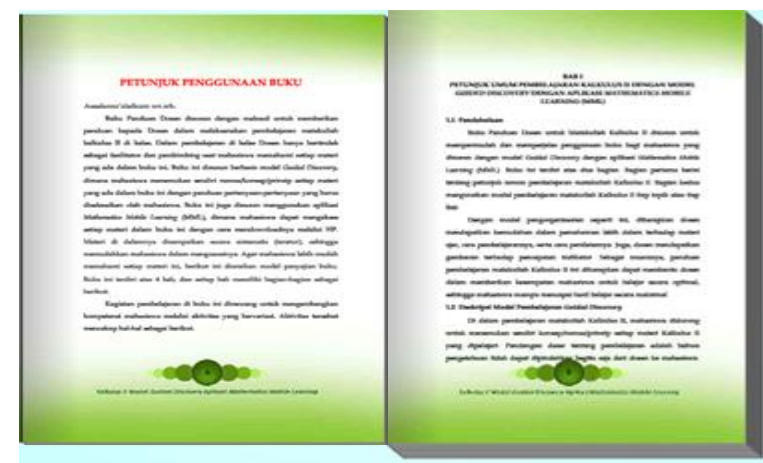

Figure 5: General Guidelines of MML of Calculus II

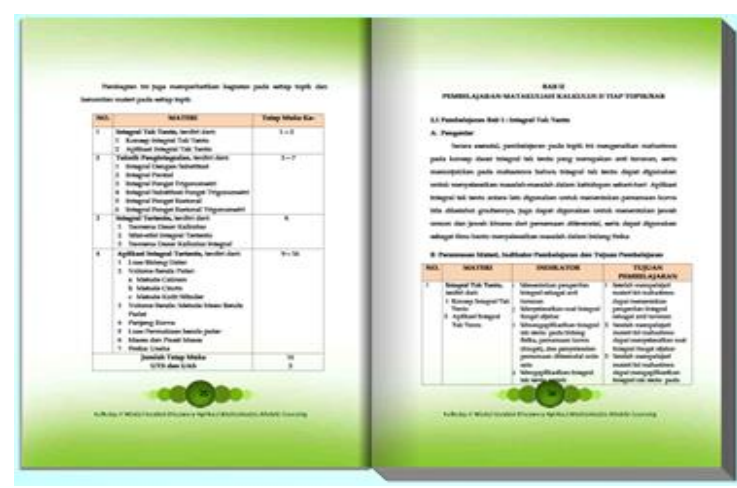

Figure 6: The Teaching of MML of Calculus II

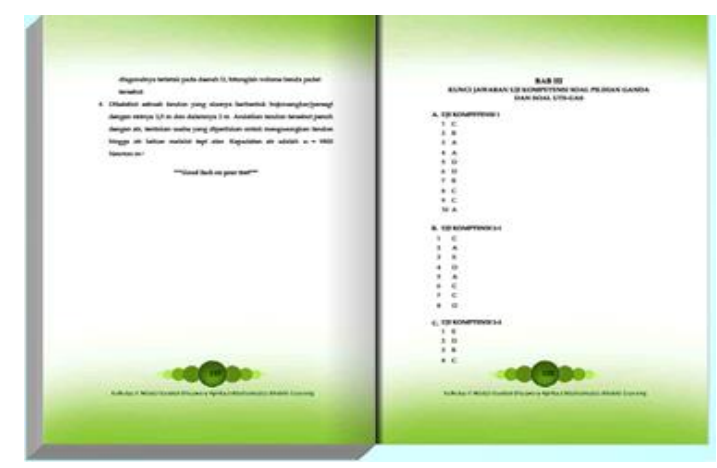

Figure 7: Answer Key of the Competence Test

\section{The Results of Expert Judgment}

The expert judgment was conducted by three experts, namely an expert of media and instructional design, mathematics instruction, and mathematics. Those experts evaluated the products of the research including the guide book for lecturers. The aspects of MML media of Calculus II evaluated are: (1) display, (2) materials, (3) worksheet and competence test, and (4) language. The aspects of the guide book evaluated are: (1) Display, (2) materials, and (3) language. The results of the evaluation are presented in Table 1 below.
Table 1. Data of the Results of the Expert Judgment on MML of Calculus II and Guide Book for Lecturers

\begin{tabular}{|c|c|c|c|c|c|}
\hline \multirow{2}{*}{ No. } & \multirow{2}{*}{ Aspect } & \multicolumn{4}{|c|}{ Score } \\
\hline & & 4 & 3 & 2 & 1 \\
\hline \multicolumn{6}{|c|}{ MML of Calculus II } \\
\hline 1. & Display & 14 & 10 & & \\
\hline 2. & Materials & 16 & 5 & & \\
\hline 3. & $\begin{array}{l}\text { Worksheet and } \\
\text { Competence Test }\end{array}$ & 13 & 5 & & \\
\hline 3. & Language & 7 & 5 & & \\
\hline \multicolumn{6}{|c|}{ Guide Book for Lecturers } \\
\hline 1. & Display & 9 & 6 & & \\
\hline 2. & Materials & 11 & 13 & & \\
\hline & Total & 70 & 44 & & \\
\hline & Percentage & 61.40 & 38.60 & & \\
\hline
\end{tabular}

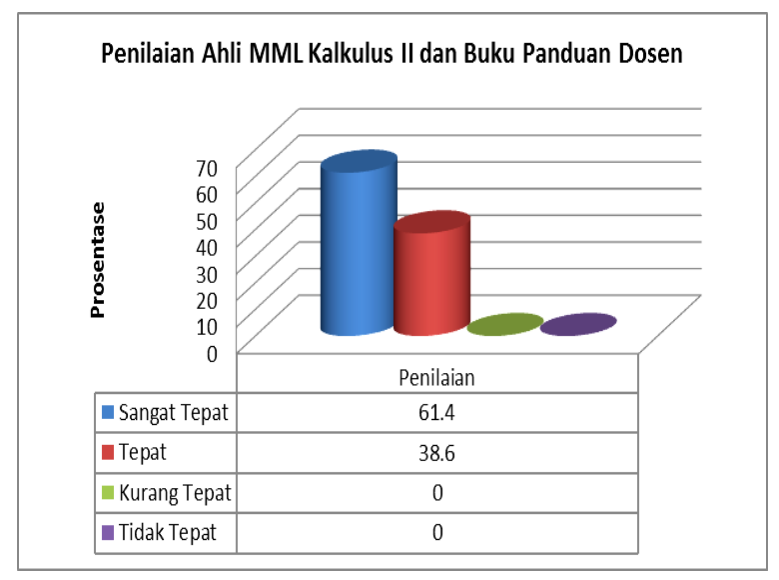

Figure 8. Expert Judgment on the MML of Calculus II and Guide Book for Lecturers

According to the experts, in general the aspects of the research products (MML of Calculus II and Guide Book for Lecturers) that have been developed were very appropriate $(61.40 \%)$, appropriate $(38.60 \%)$, and no aspect was considered either less appropriate or appropriate. The aspects of display and language were considered as very appropriate. It shows that the research products were feasible for the next validation.

\section{The Results of Analysis by Practitioners}

The analysis of the research products (MML of Calculus II and a guide book for lecturers) was conducted by two practitioners 
(lecturers of Calculus II). They analyzed both research products, namely MML of Calculus II and a guide book for lecturers. The aspects being analyzed cover (1) materials/content; (2) worksheets and competence test; (3) display; and (4) language. The complete results of the analysis can be seen in Table 2 below.

Table 2. Data of Evaluation by Practitioners on MML of Calculus II and Guide Book for Lecturers

\begin{tabular}{llrrr}
\hline \multirow{2}{*}{ No. } & \multicolumn{1}{c}{ Aspect } & \multicolumn{3}{c}{ Score } \\
\cline { 2 - 5 } & \multicolumn{1}{c}{3} & 2 & 1 \\
\hline MML of Calculus II & & & \\
1. $\quad$ Materials/Content & 17 & 7 & \\
2. $\quad$ Worksheets and & 11 & 1 & \\
& Competence Test & & & \\
3. $\quad$ Display & 11 & 5 & \\
4. $\quad$ Language & 8 & 0 & \\
Guide Book for Lecturers & & & \\
1. $\quad$ Display & 12 & 4 & \\
2. $\quad$ Materials & 7 & 3 & \\
$\quad$ Total & 66 & 20 & \\
$\quad$ Percentage & 76.74 & 23.26 & \\
\hline
\end{tabular}

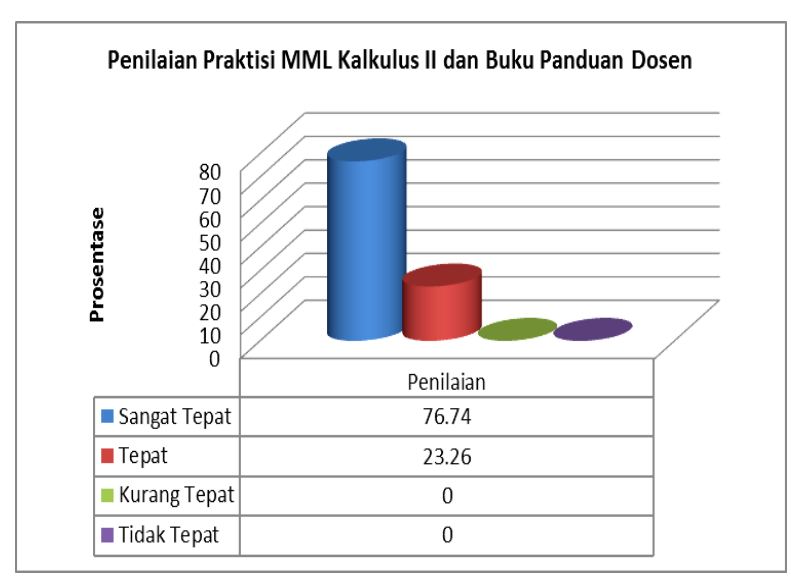

Figure 9: Evaluation by Practitioners of
MML dan Panduan Dosen

According to the practitioners, in general the research products (MML of Calculus II and Guide Book for Lecturers) that have been developed were very appropriate $(76.74 \%)$, and appropriate $(23.26 \%)$, and no aspect was considered as less appropriate and inappropriate.

The aspects of display, materials, and language in general were also considered very appropriate by the practitioners. It shows that the research products were feasible for the next validation.

\section{The Results of Analysis by a Small Group of Students}

The analysis was carried out by distributing questionnaires to 13 students of Mathematics Education Study Program of Teaching and Educational Science Faculty of Malang Islamic University to reveal the responses and types of handphones that could access Mathematics Mobile Learning (MML) of Calculus II. They were required to download the materials in the MML by using handphones through www.kalkulus-fkip-unisma.blogspot.com. The students who could not download the materials could transfer them through bluetooth. The results of the analysis showed that every material in the MML of Calculus II could be accessed through a number of JAVA-based types of handphones, such as Nokia E 63, Nokia Asha 210, Nokia 7100S, Nokia X2-00, Sony Ericsson K550, Samsung C301, Mito 880, dan Cross CB 80, and Android handphones, such as Samsung Android tipe GT-S5360, GT-C3262, GT-P3100, GT-I8150, Smartfren Android C, LG Android, and Blackberry. The students could operate the the application of MML well and without any obstacles. They could access the materials through handphones, open the program, open the home menu, open the menu of objectives and concept map of every material, open the menu of competence test of every material, open the menu of help and about.

The analysis of MML of Calculus II by the students includes the aspects of (1) display, (2) language, (3) materials, and (4) worksheets and competence test. The complete results of the analysis can be seen in Table 3 .

Based on the small scale analysis, in general the research product (MML of Calculus II) that has been developed was very appropriate $(37.82 \%)$, and appropriate $(51.60 \%)$, less appropriate $(10.58 \%)$, and no aspect was considered inappropriate. The aspects of display, language, materials as well as worksheets and competence test were considered appropriate by 
the students. It shows that MML of Calculus II was appropriate to implement in the teaching process as a guide by the students for learning.

Table 3. Data of the Results of the Analysis on MML of Calculus II by a Small Group of Students

\begin{tabular}{|c|c|c|c|c|c|}
\hline \multirow{2}{*}{ No. } & \multirow{2}{*}{ Aspect } & \multicolumn{4}{|c|}{ Score } \\
\hline & & 4 & 3 & 2 & 1 \\
\hline \multicolumn{6}{|c|}{ MML of Calculus II } \\
\hline 1. & Display & 23 & 47 & 21 & \\
\hline 2. & Language & 18 & 29 & 5 & \\
\hline 3. & Materials/Content & 41 & 47 & 3 & \\
\hline \multirow[t]{3}{*}{4.} & $\begin{array}{l}\text { Worksheets and } \\
\text { Competence } \\
\text { Test }\end{array}$ & 36 & 38 & 4 & \\
\hline & Total & 118 & 161 & 33 & \\
\hline & Percentage & 37.82 & 51.60 & 10.58 & \\
\hline
\end{tabular}

\section{Penilaian Kelompok Kecil Mahasiswa MML Kalkulus II}

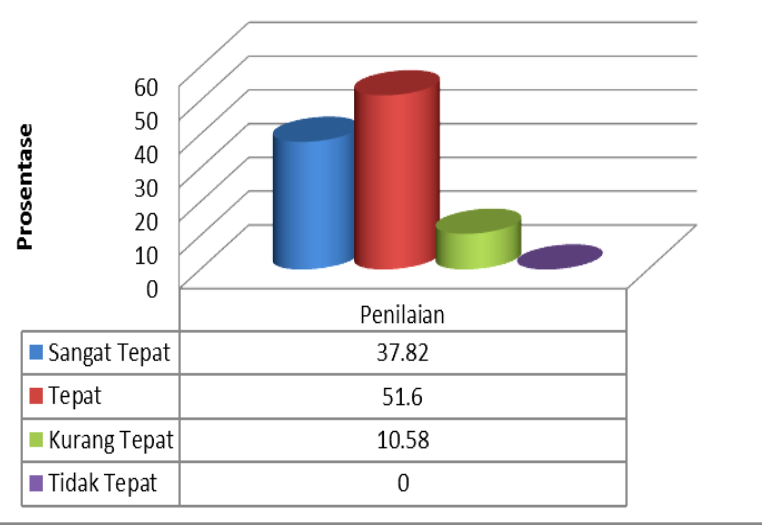

Figure 10. Evaluation by a Small Group of Students Using MML of Calculus II

\section{The Results of Students' Responses}

Fifty students analyzed Mathematics Mobile Learning (MML) Media of Calculus II using the guided discovery model. They gave their opinions about the media. The questions the students had to respond are (1) Do they enjoy learning Calculus II by using the Mathematics Mobile Learning (MML) Media of Calculus II? (2) Do they like using handphones as media for learning the materials of Calculus II so handphones are used not only for telephoning and sending messages? (3) Do they find it easy to use the Mathematics Mobile Learning (MML) Media of Calculus II through hand- phones? (4) Do they like the materials of Calculus II presented in the Mathematics Mobile Learning (MML) Media of Calculus II by using the guided discovery model? (5) Do they understand the sentences in the Mathematics Mobile Learning (MML) Media of Calculus II? (6) Do they enjoy discovering concepts or principles, and doing exercises in the Mathematics Mobile Learning (MML) Media of Calculus II? (7) Do they like the Mathematics Mobile Learning (MML) Media of Calculus II better than common textbooks?

In general, the students liked the product. $86.27 \%$ of them liked, understood, and used the product easily. $13.73 \%$ of them did not like, understand, use it easily.

\section{The Result of Field Test (Experimental Re- search)}

The research design in the field test is pre-test - post-test control group design of quasi experimental study. The data analysis technique used was paired t-test, in which the parametric prerequisite tests, namely normality test using Lilliefors (Kolmogorov-Smirnov) test and variant homogeneity test using Levene test were conducted first.

The research subjects were the semester two students of Mathematics Education Study Program of Teaching and Educational Science Faculty of Malang Islamic University taking Calculus II. There were classes of Calculus II, namely Class II A (35 students), Class II B (34 students), and Class II C (29 students) with a total of 98 students. The subjects were appointed by employing the purposive sampling technique - taking two subject groups with the total of 59 students consisting of 29 students from Class II C as the control group and 30 students from Class II A and II B as the experimental group. The experimental group were those who had JAVA-based, android, or blackberry handphones that can access the media of Mathematics Mobile Learning (MML) of Calculus II online through internet or offline. The competences in all topics in the media of Mathematics Mobile Learning (MML) of Calculus II were measured. 
Table 4. t-Test of the Post-test of the Experimental and Control Groups

\begin{tabular}{|c|c|c|c|c|c|c|c|c|c|}
\hline & $\mathrm{F}$ & Sig. & $\mathrm{T}$ & df & $\begin{array}{l}\text { Sig. (2- } \\
\text { tailed) }\end{array}$ & $\begin{array}{c}\text { Mean } \\
\text { Difference }\end{array}$ & $\begin{array}{l}\text { Std. Error } \\
\text { Difference }\end{array}$ & Lower & Upper \\
\hline $\begin{array}{l}\text { Pos Equal } \\
\text { test variances } \\
\text { assumed }\end{array}$ & .669 & .417 & 1.863 & 57 & .068 & 6.65402 & 3.57260 & -.49998 & 13.80803 \\
\hline $\begin{array}{l}\text { Equal } \\
\text { variances not } \\
\text { assumed }\end{array}$ & & & 1.858 & 55.115 & .069 & 6.65402 & 3.58191 & -.52394 & 13.83199 \\
\hline
\end{tabular}

In this study, the teaching scenarios of the experimental group were available in the guide book. In the experimental group, all subjects owned handphones that could be used to download and operate the media of MML of Calculus II easily. If some problems existed, the media was transferred through bluetooth to assure that in the teaching process they could learn the materials of Calculus II through their own handphones.

Before the test of equality of means of the post-test results was conducted, the test of equality of means of the pre-test was carried out. Based on the data analysis of the pre-test the significance value (sig.2-tailed) by using ttest was 0.266 . Because the significance value was greater than 0.05 , based on the criteria of decision making, $\mathrm{H}_{0}$ was accepted. It shows that the learning achievements of the students in the experimental and control groups taking Calculus II in the pre-test were signifcantly different.

From the analysis of the post-test data, the output of the normality test by uisng Lilliefors (Kolmogorov-Smirnov) normality test was obtained. The significance value of the experimental group was 0.055 and that of the control class was 0.200 . The two significance values were greater than 0.05 , so the samples of the two groups came from a normally distributed population. The output of homogeneity test by using Levene test was also obtained. The significance value was 0.669 . Because it was greater than 0.05 , it can be concluded that the varians of the experimental and control goups were the same.

From the normality and homogeneity tests, the data with normal and heterogeneous distributions were obtained. Therefore, the test of the equality of means by using t-test through Independent Sample T-Test in SPSS 17.0 for Windows program could be carried out with the equal varians assumed and 0.05 significance level. The results of the t-tes are as Table 4.

In Table 4 the testing criteria based on the t-test of the post-test above were just effective for the 2-tailed test. It is shown that $t_{\text {calc }}$ for the post-test scores of equal varians assumed was 1.863 whereas $\mathrm{t}_{1-\alpha}$ obtained from the interpolation was $t_{0.95(57)}=1.672$. Based on both values, the result was the $\mathrm{t}_{\text {calc }}>\mathrm{t}_{0.95(57)}$, so $\mathrm{H}_{0}$ was rejected. Thus, it can be concluded that the students' achievements in learning Calculus II by using guided discovery-based Mathematics Mobile Learning (MML) are better that those using the conventional instruction. Therefore, it can be concluded that the guided discoverybased learning materials in Mathematics Mobile Learning (MML) of Calculus II are effective to use in learning Calculus II.

\section{Discussion}

This study is aimed at developing the guided discovery-based learning materials of Calculus II with the application of Mathematics Mobile Learning (MML). The development of the learning materials is one of the inseparable components of the learning system (Dick and Carey, 2001: 36-37). The products of the study are guided discovery-based MML media of Calculus II for the students and a guide book for the leacturers. Nasution (2005:103) states that learning materials are one of the beneficial tools of instructional technology: (1) assisting educators in implementing a curriculum; (2) guiding 
the decision of what teaching method to use; (3) providing learners the opportunity to review the learning materials or learn the new learning materials; and (4) offering a continuity of sequential lessons in the class despite the changes of the teachers.

Based on the elaborated data analysis, the research products, MML media of Calculus II and a guide book for lecturers, were considered very appropriate in terms of the display, materials, and language. The appropriateness evaluation by the experts and practitioners in general were $61.40 \%$, and $76.74 \%$ respectively. The evaluation by a small group of students in those aspects were also very appropriate $(37.82 \%)$, and appropriate $(51.60 \%)$.

The guide book is developed to help the leacturers implement the MML media of Calculus II in the class. Both the media and the guide book are equipped with manuals. They direct both the students and lecturers in using the learning materials. The manuals consist of topics to learn and descriptions of competences measured after using the learning materials. According to Dick and Carey (2001:36-37), manuals contain the directions of using all learning resources available in the materials. The directions are the rational and general directions of using the materials. They contain the explanation of what the students and lecturers have to do inthe beginning and end of activities.

The development of product uses the application of Mathematics Mobile Learning (MML) as a form of learning specifically utilizing mobile devices and communication technology, namely handphones. The learning by using the media is expected to provide the students with new experience to facilitate their learning and increase their learning motivation. It is based on the statement by Asyhar (2011: 28) defining teaching media development as a creative and systematic effort to create experience that can teach learners. The development of teaching media should not be based on the teachers' preferences, but on the suitability of the media with the students' characteristics in addition to other criteria such as practicality, accessibility, and quality.
The product is learning materials using the application of Mathematics Mobile Learning (MML) as a form of learning specifically using mobile devices and communication technology, namely handphones. The emergence of mobile leraning as teaching media is due to the very rapid penetration of mobile devices, greater in number than PCs, and more easily operated (Darmawan, 2012:15). It is in line with Yuniati (2011:91) saying that mobile learning enables handphones, used to be utilized to send messages, make phone calls, and access the internet, to serve as complete learning tools containing learning materials. With mobile learning, one can perform learning more flexibly in terms of place and time than learning by using the concept of e-learning (Tamimuddin, 2008: 2).

Based on the research findings, the guided discovery-based MML learning materials of Calculus II can be effectively used in learning Calculus II. The findings show that handphones are effective to be used as media for the students in learning. It is in line with Attewell (2005:2) finding that mobile learning gives the following benefits: (1) enabling learning to take place really wherever and whenever; (2) enlivening or offering more variations to conventional teaching; (3) reducing formality considered uninteresting or frightening by non-traditional learners; and (4) facilitating learning experiences both individually and collaboratively.

\section{CONCLUSION}

The products of the study are guided discovery-based MML media of Calculus II and a guide book for lecturers. Based on the evaluation by the experts and practitioners, as well as a small group of students the research products are very appropriate to be used as a learning guide because they can utilize handphones as learning media for the students. The students' responses show that they can learn the materials of Calsulus II through handphones. In this way, handphones are used not only as a means of telephoning and sending messages, but also as learning media. The students also find that the materials available in the handphones are 
readable and easy to learn, the language is easy to understand so they facilitate the students' learning. In general, $86.27 \%$ of the students say that they enjoy, understand, and find it easy to use the research product. $13.73 \%$ of them do not have the same opinion about it.

MML media of Calsulus II can run well for certain JAVA-based handphones, such as Nokia E 63, Nokia Asha 210, Nokia 7100S, Nokia X2-00, Sony Ericsson K550, Samsung C301, Mito 880, and Cross CB 80, as well as Android handphones like Samsung Android type GT-S5360, GT-C3262, GT-P3100, GTI8150, Smartfren Android C, LG Android, and Blackberry. It shows that many types of handphones can be used to access and run the MML media. Therefore, it is expected that many students can improve their motivation to learn Calculus more easily. All the subjects of the try-out can operate the MML application through their own handphones without any obstacles. They have a good ability in operating the MML. It means that they can access the materials through handphones, open the program, the home menu, the menus of objectives and competence test of each material, the menu of materials of each material, the menu of competence tests of each material, the menu of help, and the menu of about.

Based on the t-test of the post-test for the 2-tailed t-test, it is shown that $t_{\text {calc }}$ for the posttest scores of equal varians assumed is 1.863 whereas from $t_{1-\alpha}$ the result of interpolation is $t_{0,95(57)}=1.672$. Based on the obtained value, the value of $t_{c a l c}>t_{0,95(57)}$, so $\mathrm{H}_{0}$ is rejected. It can be concluded that the achievements of the students in learning Calculus II by using guided discovery-based learning materials of Mathematics Mobile Learning (MML) of Calculus II are better than those of the students using the conventional learning. Thus, it can be concluded that the guided discovery-based learning materials of Mathematics Mobile Learning (MML) of Calculus II are effective to be used in learning mathematics, especially Calculus II.

\section{ACKNOWLEDGEMENTS}

An expression of gratitude is addressed to the Ministry of Education and Culture of the Republic of Indonesia through Coordinator of Private Universities of Region VII of East Java, providing the fund for the study, with the Assignment Letter Number 016/SP2H/P/KM7/ 2014 issued on 03 April 2014. Great thanks also go to the Rector and Head of Centre for Research and Community Service of Malang Islamic University for giving the opportunity to conduct the study. The writer would also like to thank the Editor and Staff of Jurnal Ilmiah Cakrawala Pendidikan of Yogyakarta State University for publishing this article.

\section{REFERENCES}

Andy, Yonatan. 2007. Perancangan dan Implementasi Mobile Learning untuk Pembelajaran Bahasa Jepang Berbasis Brew. Bandung: STEI ITB.

Ally, M., Lin, F., McGreal, R. And Woo, B. 2005. An Intelligent Agent for Adapting and Delivering Course Materials to Mobile Learners. [Online]. Tersedia: http://www.mlearn.org.za/CD/papers/Ally-an\%20intelligent.pdf, 28 Februari 2012.

Attewell, J. 2005. From Research and Development to Mobile Learning: Tools for Education and Training Providers and their Learners, www.mlearn.org.za/CD/papers/Attewell.pdf, 6 Juni 2012.

Asyhar, Rayandra. 2011. Kreatif Mengembangkan Media Pembelajaran. Jakarta: Gaung Persada Darmawan, Deni. 2012. Inovasi Pendidikan. Bandung: PT Remaja Rosdakarya Offset.

Darmawan, Deni. 2012. Teknologi Pembelajaran (Cetakan Kedua). Bandung : PT Remaja Rosdakarya Offset.

Dick, Walter \& Carey, Lou. 2001. The Systematic Design of Instruction. Glenview, 
Illinois London, England: Scat, Foresman \& Company.

Ghozali, Imam. 2006. Aplikasi Analisis Multivariat dengan Program SPSS. Semarang: Badan Penerbit Universitas Diponegoro.

Nasution S. 2005. Teknologi Pendidikan. Jakarta: Penerbit Bumi Aksara.

Sugiyono. 2006. Statistika untuk Penelitian. Bandung: Alfabeta.

Tamimuddin, M. 2008. "Pemanfaatan Mathematics Mobile Learning dalam Pembelajaran Matematika." Makalah Disajikan dalam Seminar dan Lokakarya Pengembangan dan Pemecahan Masalah Pembelajaran matematika Berbasis ICT, PPPPTK Matematika Yogyakarta, 10 - 11 Juni 2008.

Thiagrajan, Sivasailan, dkk. 1974. Instructional Development for Training Teacher of Exceptional Children. Indiana: Indiana University.
Tuckman, B.W. 1999. Conducting Educational Research. Fifth Edition: Orlando, Harcourt Brace College Publisher.

Wahono, Romi Satria. 2005. Pengantar ELearning dan Pengembangannya. (Portal www.ilmukomputer.com Indonesia) Diakses tanggal 20 Agustus 2012.

Waldopo. 2002. Penelitian dan Pengembangan: Pendekatan dalam Mengembangkan Produk-produk di Bidang Pendidikan Pembelajaran. Pustekom, Jurnal Teknodik, Desember, 11(4). Pp.89-100.

Wijaya, Wisnu. 2006. Mobile Learning sebagai Model Pembelajaran Alternatif Bagi Pemulihan Pendidikan di Daerah Bencana Alam Gempa Bumi Yogyakarta. [Online]. Tersedia: http://www.usd.ac.id/06/publ_dosen/wisnu_ti/mobile.pdf, 9 Feb 2009.

Yuniati, Lukita. 2011. "Pengembangan Media Pembelajaran Mobile Learning Efek Doppler Sebagai Alat Bantu Belajar dalam Pembelajaran Fisika yang Menyenangkan." $J P 2 F$. Volume 2 Nomor 22 September 92101. 